University of Rhode Island

DigitalCommons@URI

Open Access Master's Theses

1941

\title{
Validity of Scale Analysis as a Means of Age Determination of the Winter Flounder
}

Edgar L. Arnold Jr.

University of Rhode Island

Follow this and additional works at: https://digitalcommons.uri.edu/theses

\section{Recommended Citation}

Arnold, Edgar L. Jr., "Validity of Scale Analysis as a Means of Age Determination of the Winter Flounder" (1941). Open Access Master's Theses. Paper 1396.

https://digitalcommons.uri.edu/theses/1396

This Thesis is brought to you for free and open access by DigitalCommons@URI. It has been accepted for inclusion in Open Access Master's Theses by an authorized administrator of DigitalCommons@URI. For more information, please contact digitalcommons-group@uri.edu. 


\section{VAIIDITY OF SCAIE ANALYSIS}

AS A MEANS OF AGE DETER-

MIINATION OF THE WINTER

FIOUNDIR

BY

FDGAR I. ARNOLD, JR.

\section{A THES IS SUBRITTED IN PARTIAL FULFIIIMEINT}

OF THE REQUIREMIENTS FOR THE DEGREE

OF

MASTER OF SCIENCE

IN

ZOOLOGY

RHODE ISIAND STATE COLLEGE 
MASTER OF SCIENCE THESIS

OF

EDGAR L. ARNOLD, JR.

Approved:

Major Professor

Charles I tran

Head of Department
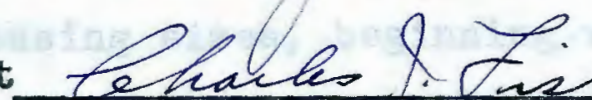

Dean of science Itavold Lrourma

chairman, Graduate comittee Davaldus 2

Rhode Island State College 
ABSTRACT

A steadily decreasing yield in the winter flounder stock has led to a series of investigations into its life history by the Federal Fish and Wildife Service, in an attempt to ascertain the cause of its decline. Disagreement in age determination by seale analysis has been responsible for much delay in solving an urgent problem. To devise an accurate method for determining age by scale reading, a series of specimens of gradually increasing sizes, beginning with those known to be of the currently-spawned stock, were selected and their scales subjected to detailed study.

Results showed that age can definitely be determined by scale analysis when accompanied by essential supplementary data on length and date of capture. Age determination of 509 specimens from the population of Point Judith Pond checked with the findings of ear-bone readings of age. 
TABLE OF CONTPENTS

I. INTRODUCTION........................... 3

II. REVIEW OF THE LITERATURE................. 4

III. INVESTIGATION........................... 5

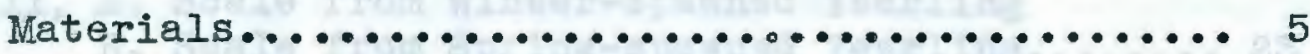

Methods of Procedure.................... 7

Explanation of Terms..................

scale structure.................... 9

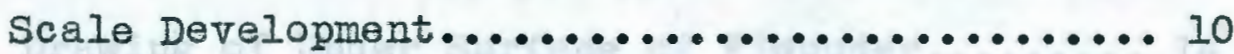

Establishment of Area for Scale Removal....... 10

Mounting the scales...................... 15

Scale Analysis...................... 15

IV. RESULTS AND DISCUSSION. ................. 17

Other Methods of Age Determination by Scale

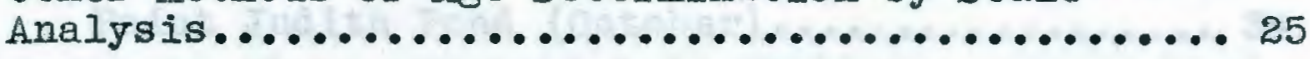

Year class Seperation by Size Iimitations.......27

False Winter Bands or False Checks............ 27



Possibility of Racial Differences..............3I

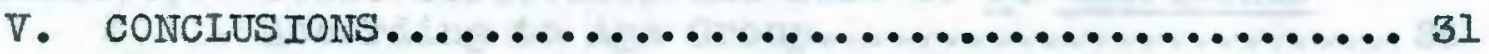

VI. AGKNOWLEDGMENTS ...................... 36

VII. BIBIIOGRAPHY........................ 37 
Index of Plates, Figures and Tables

Plate I, Flounder Scale Showing More Than Three

Plate II, A. Scale from Largest 0

B. Scale from Smallest Yearling...........2l

Plate III, A. Scale from Winter-spawned Yearling

B. Scale from Spring-spawned Yearling....... 23

Plate IV, Scale from Two Year Old Fish.............. 24

Plate $\nabla, \quad$ Scale Showing False Check............... 30

Figure 1, Drawing of Upper Surface of Flounder........ 13

Figure la, Drawing of Under Surface of Flounder........ 14

Figure 2 , scale from Young specimens............... 18

Figure 3, Scale from Young Specimens.............. 19

Figure 5, Length Frequencies of April Population

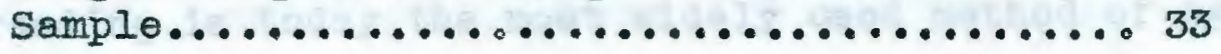

Figure 6, Composition of Winter Flounder Population of Point Judith Pond (October).............. 34

Table 1, Degree of Legibility of Areas for Scale

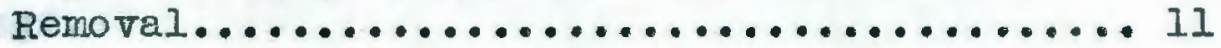

Table 2, Data on Gradated Series of Specimens........ 35

Table 3, Age Determination by Winter Band Location.... 26

Table 4, Scale Structures and Size of $\underline{P}$. americanus According to Age Group................. 26

Table 5, Percentage of Age Groups in the october Point Judith Pond Winter Flounder Population. 31 


\section{INTRODUCTION}

The recent alarming decline in the abundance of the winter flounder, Pseudopleuronectes americanus, in the coastal waters of New England and New York has caused such concern among fishery investigators that all possible information on the biology of this species is urgently desired.

The object of the present investigation has been a) to overcome by scale analysis a serious obstacle, namely, inability to determine with certainty the age of $\underline{P}$. americanus, and $b$ ) provided an accurate method could be devised, application of it in an analysis of the age composition of a winter flounder population.

Scale reading is today the most widely used method of age determination in fish. With some forms, this method is fairly simple, in others it is impossible to correlate growth with scale markings.

The winter flounder has proven to be a difficult subject for scale analysis because it lacks distinct annuli or winter rings typical of fishes ranging southward of cape cod. It is a northern fish which grows to some extent throughout the entire year. The scales correspond in growth, hence exhibit no definite annuli indicative of winter cessation. Instead, there occur alternate narrow, dark bands representing winter growth, and broad, light bands from more rapid growth in warmer water at other seasons. 


\section{$-4-$}

Uncertainty in reading the early scale development has been the real obstacle in the case of the winter flounder. Different investigators give different interpretation regarding the first year's growth as indicated on the scale. So long as this confusion remains, no population analysis will be complete.

In attempting to develop a method of age determination by scale analysis, the author has had in mind limitations in the application. of the "otolith" method. Ear bones tend to become inereasingly opaque with advancing age and also, to obtain them the fish must be killed. Since several important aspects of fishery research involve liberation of tagged specimens after study, scale reading forms a partieularly desirable method, for scale samples can be removed without causing injury.

\section{REVIEW OF IITERATURE}

The essential relief features of the fish scale were first described by Boreljus in 1856. Later, with the introduction of the microscope, scales were subjected to more detailed study by such investigators as von Leeuvenhoeck and I. Agassiz, but it was not until 1898 that they were regarded as a means by which age and other salient features in the life history of the fish could be determined. It was then that Horfbauer, working with carp scales, observed on their surface, concentric rings which he considered to be indicative of growth 
(Taylor, 1914). The impetus afforded by these findings has resulted in a long series of important investigations dependent upon accurate age determination. Subsequent workers established the validity of Hoffbauer's conelusions that surface markings were indeed indicative of periodic growth.

Iittle has been done on the scales of the winter flounder, however, and references having a direct bearing on the present problem are few.

B. B. Rae's work on the lemon sole (1939), a closely related species, are in accord with the author's findings regarding the best areas from which scales giving consistent and true readings can be removed.

However, the most recent federal surveys in Long Island waters by Lobell and Perlmutter show definite disagreement on age determination in $\underline{P}$. americanus, particularly regarding what markings are indicative of the first year's growth.

\section{INVESTIGATION}

Materials

The scope of the present investigation has been limited to the immediate vicinity of Point Judith Pond. Approximately 800 winter flounders ranging in size from 21 millimeters to 355 millimeters were collected for study. These can be divided into three groups according to their time of capture. 
1) 509 specimens taken October 31,1940 in Point Judith Pond.

2) 60 specimens taken June - August, 1940 in Point Judith Pond and Lower Narragansett Bay.

3) 208 specimens taken April 9 - 19, 1941 in Point Judith Pond.

Specimens obtained in autumn and spring were taken by dragging with a shrimp trawl from the Narragansett Narine Laboratory power boat. The meshes of this trawl were of $11 / 2$ inch stretch to assure the capture of the smallest members of the population. Hauls were of 45 minutes' duration and were repeated when necessary to obtain sufficient specimens.

The 60 flounders taken during the summer months were part of the catches made with 50 and 150 foot haul seines at selected stations along the shore. It was from this group that the smallest specimens for scale study were selected.

The time of autumn dragging, October 3lst, was chosen to insure catching the larger fish which leave Point Judith Pond in late spring and return from offshore with cooling water in September. Thus a true cross-section sample of the winter flounder population of the area could be expected. Spring hauls were made prior to the departure of the larger stock, but only the smaller fish were kept to plot their lengths and wionths for determination of the possibility of racial differences. 


\section{Methods of Procedure}

\section{Explanation of Terms}

The following explanation covers special terms used in this paper.

0-year class - comprises flounders in their first year. Yearlings or "I's" - Pish which have completed one year's growth and are in their second year.

Flelds. (Taylor 1914)

1. Anterior field is the portion of a scale inclosed in the scale pocket and directed toward head of fish.

2. Posterior field is the exposed portion of the scale. In the winter flounder it is the region where the spines are formed. Herein lies the focus or nucleus of scale, in fish over $30 \mathrm{~mm}$. protected by a flap of dermis closely adhering to the scale surface. This protective structure must be removed to study focus and adjacent circuli.

3. Inferior side is that portion next to the body. Exterior side is the sculptured surface.

Focus or nucleus - that part of the scale first laid down in early development, and in P. americanus it is located in the posterior field of the scale about 1/10 scale length from margin or periphery. 


\section{Plote I}
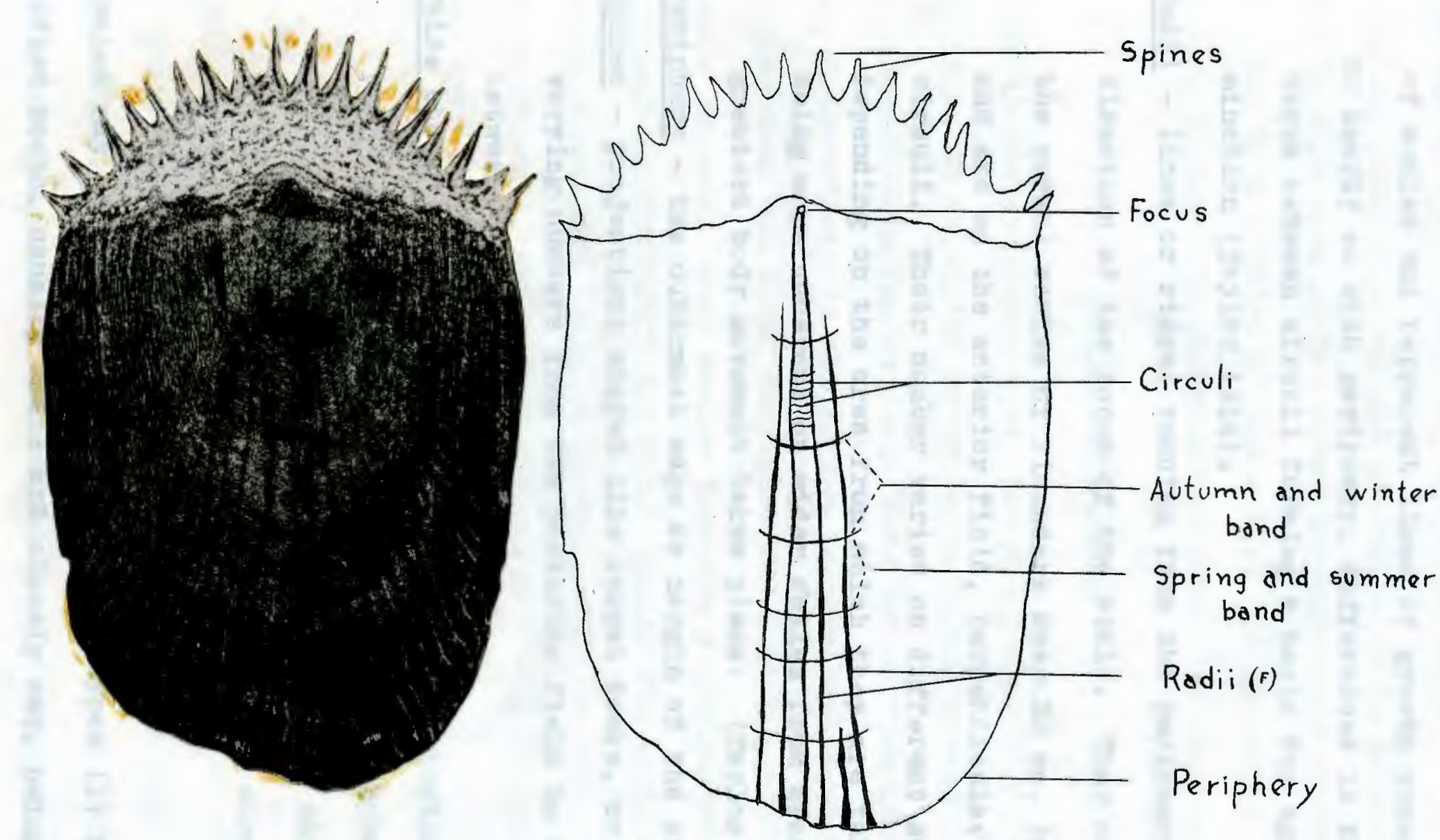

Flounder scale showing more than three years of growth 
Circuli - These structures occur on the exterior surface of scales and represent lines of growth concentric or nearly so with periphery, differences in the distance between circuli forming a basis for age determination (Taylor 1914).

Radif - lines or ridges running from the periphery in the direction of the focus of the scale. They occur in the normal scales of flounders over $30 \mathrm{~mm}$. In length, and are on the anterior field, perpendicular to the circuli. Their number varies on different scales depending on the area from which they are taken, being more numerous on wider scales from areas where greatest body movement takes place. (Taylor 1914). Periphery - the outermost edge or margin of the scale. Spines - projections shaped like carpet tacks, arising in varying numbers from the posterior field in the area between the focus and periphery.

False checks - abnormal bands of cireuli indicating temporary retarding of growth and commonly appearing as a band of narrowly spaced circuli (winter characteristic) inserted among the broader summer oirculi. Scale structure

Scales may be classified in four basic types (1) Placoid, or modified teeth, usually small and closely set, being found in elasmobranchs (sharks, skates and rays) (2) Ganoid, which 
may vary in form and structure. These are commonly rhombic in shape and form the plates of "armored" fishes. (3) Cycloid, which overlap like shingles and are embedded in pockets in the corium with only part of the outer smooth margin exposed. ctenoid, the type studied by the author and possessed by most of the bony fishes. (Classification after Taylor 1914).

\section{Scale Development}

Ctenoid and cycloid scales, the types occurring in P. americanus, begin as calcified spots which slowly extend in their dermal pockets, adhering by their inferior surfaces and peripheries. Scleroblasts in the corium secrete two layers, the upper homogenous and bony, the under fibrillar, containing a calcareous deposit. Such scales increase in thickness and area by continued scleroblastic activity, successive additions resulting in concentric lines of growth. It is these lines of growth, or circuli, which form the basis of age determination. (Adapted from Taylor 1914).

\section{Establishment of Area for Scale Removal}

Upon examining scales removed from different regions of P. americanus, it was plainly noticeable that there existed on the same fish a difference in shape, size, and even in the number of circuli. Seales taken from the extreme caudal area were long and narrow, while those taken only slightly anterior 
Table 1

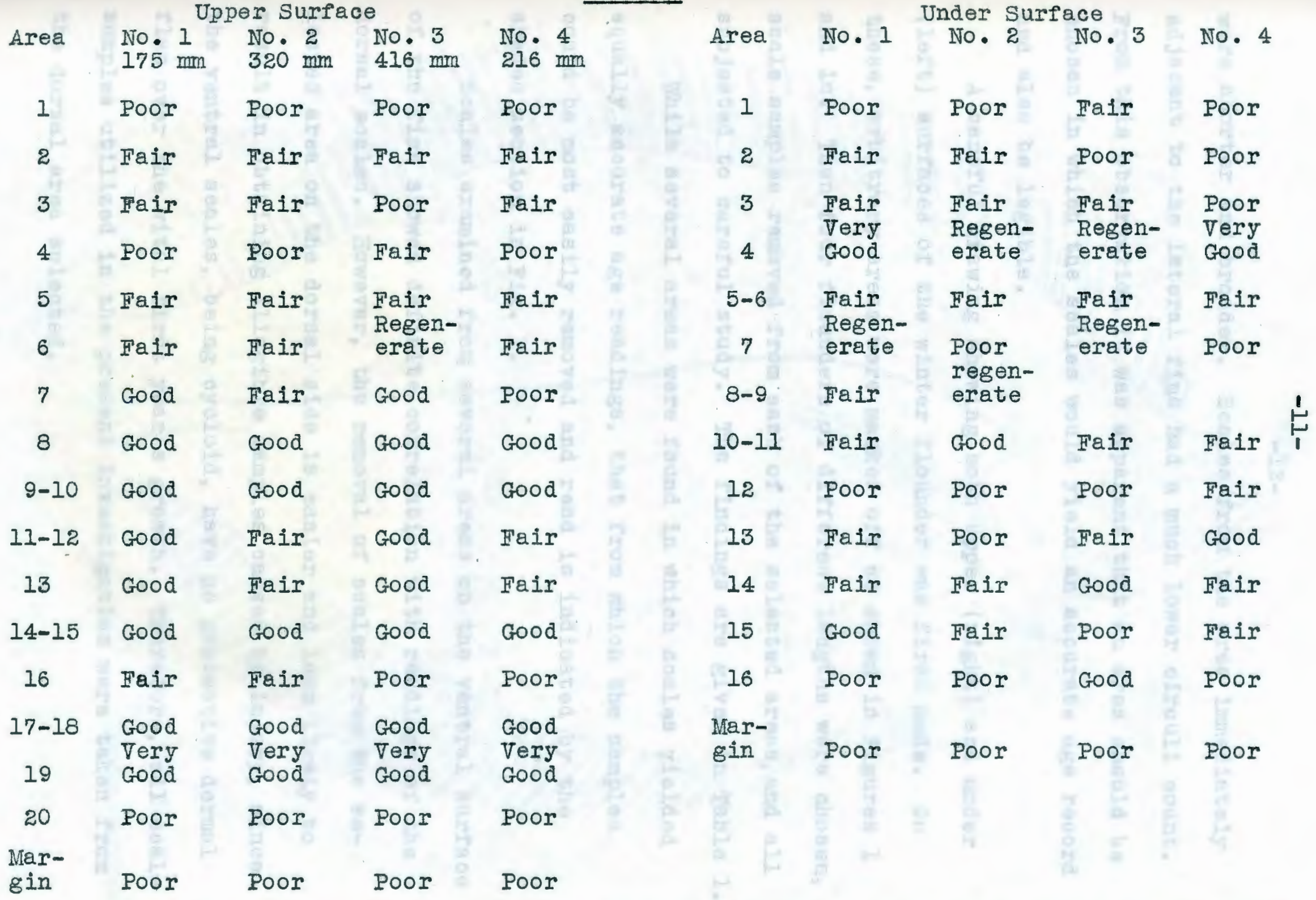

Text: Degree of legibility of scales from selected areas on four specimens of $\underline{\text { P. americanus }}$ 
were shorter and broader. Scales from the area immediately adjacent to the lateral fins had a much lower cireuli count. From this observation it was apparent that an area should be chosen in which the seales would yield an accurate age record and also be legible.

A careful drawing showing both upper (right) and under (left) surfaces of the winter flounder was first made. On these, arbitrary areas were marked off as shown in Figures 1 and 1a. Then four flounders of different lengths were chosen, scale samples removed from each of the selected areas, and all subjected to careful study. The findings are given in Table 1. While several areas were found in which scales yielded equally accurate age readings, that from which the samples could be most easily removed and read is indicated by the shaded section in Fig. 1 .

Scales examined from several areas on the ventral surface of the fish showed definite correlation with readings of the dorsal scales. However, the removal of scales from the selected area on the dorsal side is easier and less likely to result in obtaining illegible samples caused by injury, since the ventral scales, being oyoloid, have no protective dermal flap over the vital first year's growth. Therefore, all scale samples utilized in the present investigation were taken from the dorsal area selected. 


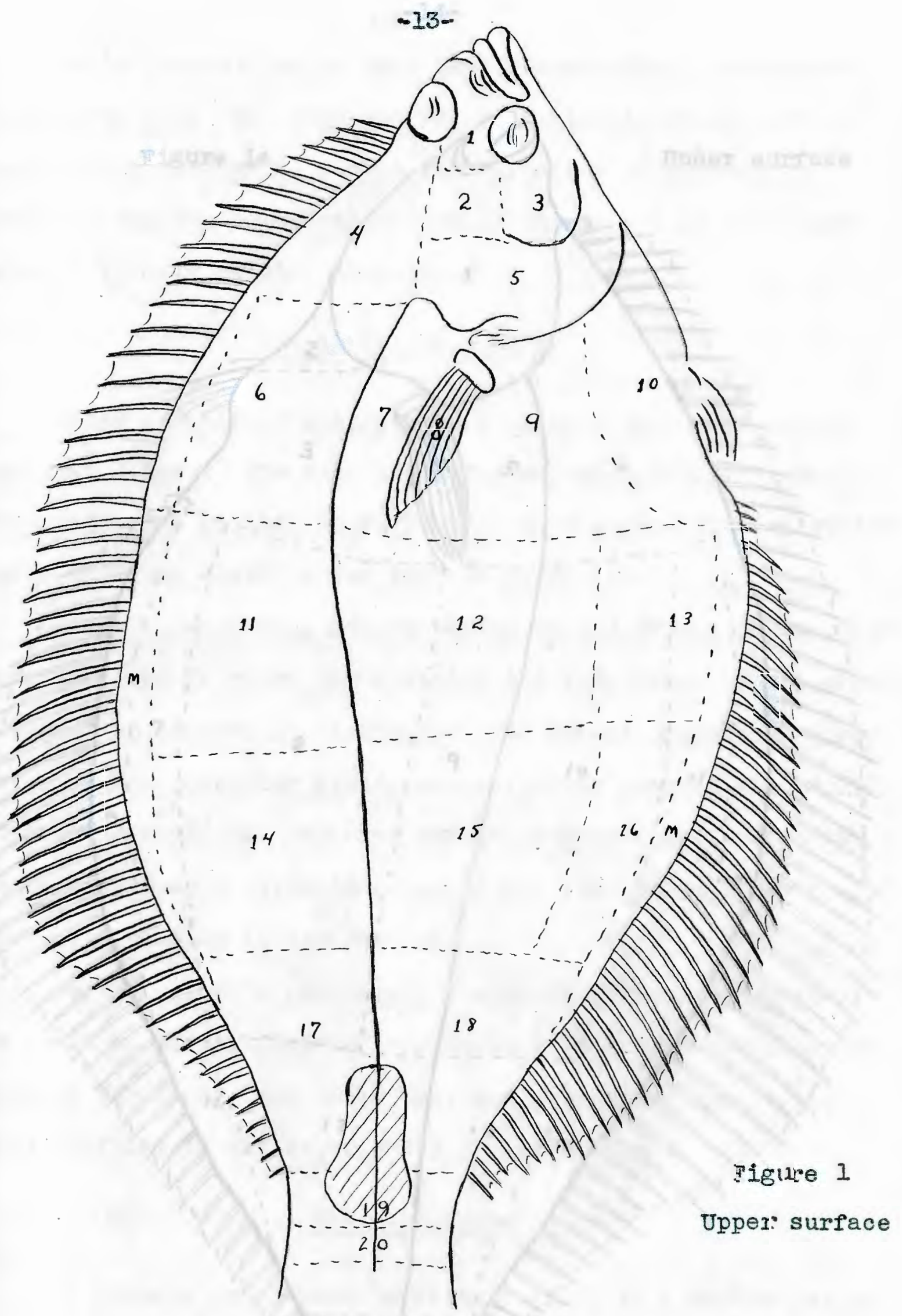


$-14-$

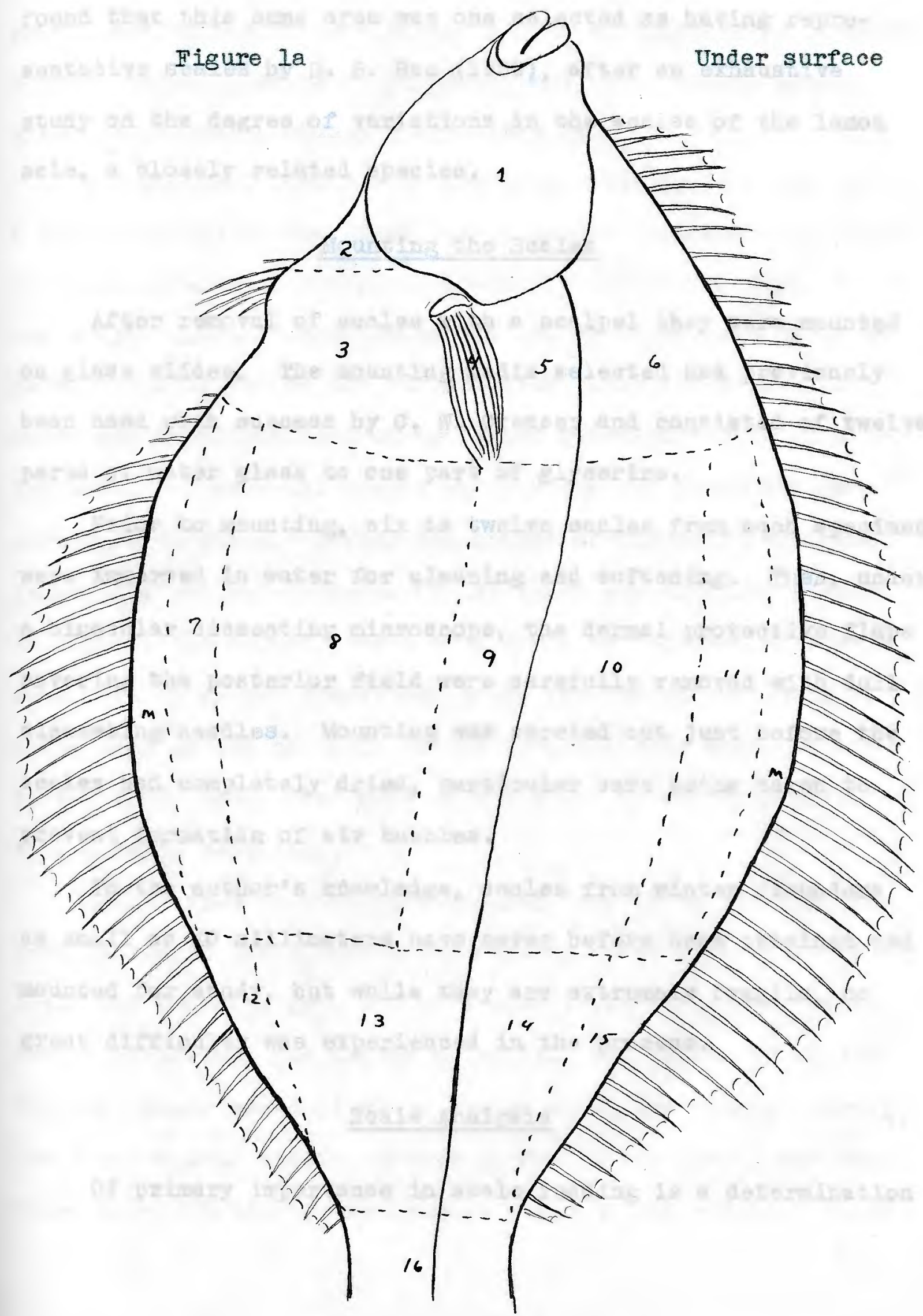


It is interesting to note that subsequently, the author found that this same area was one selected as having representative scales by B. B. Rae (1939), after an exhaustive study on the degree of variations in the scales of the lemon sole, a closely related species.

\section{Mounting the Scales}

After removal of scales with a scalpel they were mounted on glass slides. The mounting media selected had previously been used with success by $C$. W. Creaser and consisted of twelve parts of water glass to one part of glycerine.

Prior to mounting, six to twelve scales from each specimen were immersed in water for cleaning and softening. Then, under a binocular dissecting microscope, the dermal protective flaps covering the posterior field were carefully removed with dull dissecting needles. Mounting was carried out just before the scales had completely dried, particular care being taken to prevent formation of air bubbles.

To the author's knowledge, scales from winter flounders as small as 40 millimeters have never before been obtained and mounted for study, but while they are extremely fragile, no great difficulty was experienced in the process.

\section{Scale Analysis}

of primary importance in scale reading is a determination 
of the number of light and dark bands, indicating retarded growth during the coldest winter months accompanied by closely spaced circuli, and spring, summer, and early autumn growth with corresponding widely spaced circuli.

The greatest obstacle to previous investigators had been a determination of the first year's growth from scale markings. For this problem, a series of gradually increasing sizes of the winter flounder were selected, all of which were known to be representatives of the current year class (2l-24 $\mathrm{mm}$. in July) and then continued on to larger forms in search of some indication of seasonal change which would set apart the previous year's stock. Taking the number of circuli, radii and length - width measurements of the known current year's stock in summer, the former year's crop would be expected to show some sort of winter transition point indicating the limit of first year growth and part of the second. This would be expected even though fast-growing $0^{\prime}$ s might overtake in size slow-growing yearlings.

Scales from 34 flounders ranging from 21 to 170 millimeters in length (late summer and autumn), were carefully anaIyzed and averages from 6 - 10 scales taken on length; width, number of circuli and number of radii. The number of elrculi for each scale was derived by counts along the ridges between the four central radil. (Plate I, F). Scale length was measured from the tip of the longest ridge in the anterior field 
with a camera lucidar and a micrometric scale.

As an aid in analyzing the scales, camera lucida drawings were made of several from certain specimens up to and including $75 \mathrm{~mm}$. in length, and paper negatives* made of a like number of the larger fish (Fig. 2, 3 and Plate II).

\section{RESULTS AND DISCUSSION}

Examination of the scales of the smallest specimen obtained ( $21 \mathrm{~mm}$.$) revealed an average of 3.5$ eirculi (Fig. $2, A$ ), indicating that scales probably first appear when the flounder is 4-10 mm. long. These scales averaged .192 mm. in length, $.129 \mathrm{~mm}$. in width. Radii were first observed in $29 \mathrm{~mm}$. specimens. Scale measurements, the number of circuli and the number of radii gradually increased proportionate with size in the gradated series of $\mathrm{fish}$, as shown in Table 2 .

An uninterrupted growth rate in scale structure occurred in specimens up to and including $136 \mathrm{~mm}$. (No. 58), with no indication in october of winter retardation such as would have been expected had the individuals at that time completed a year's growth (Plate II, A). Evidence of growth retardation was first observed in cirouli from a $138 \mathrm{~mm}$. fish (No. 398, Plate II, B). This change did not involve a significant in-

Paper negatives were made of the scales by projecting their images upon sensitized enlarging paper through a microscope with a $40 \mathrm{~mm}$. objective. This method is much easier, much less expensive and quicker by far than the commonly used process of taking pictures. 
Scales from young specimens

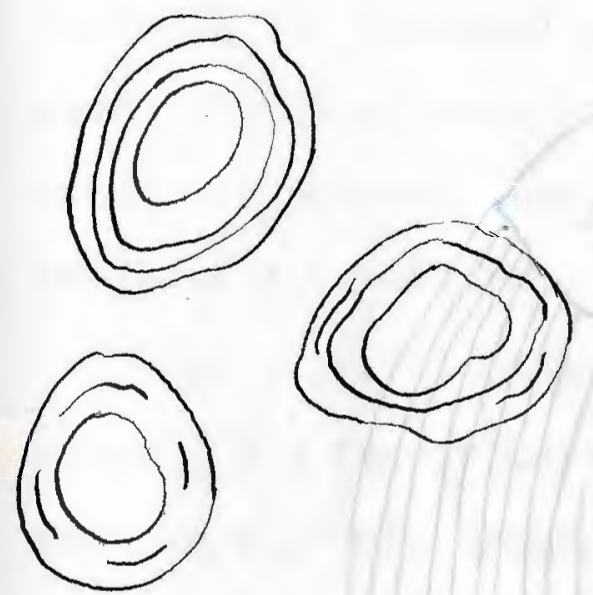

A. $21 \mathrm{~mm}$.
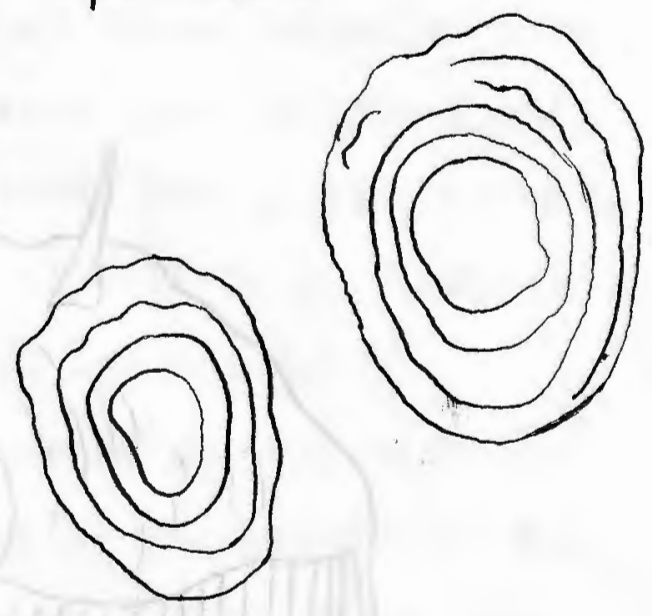

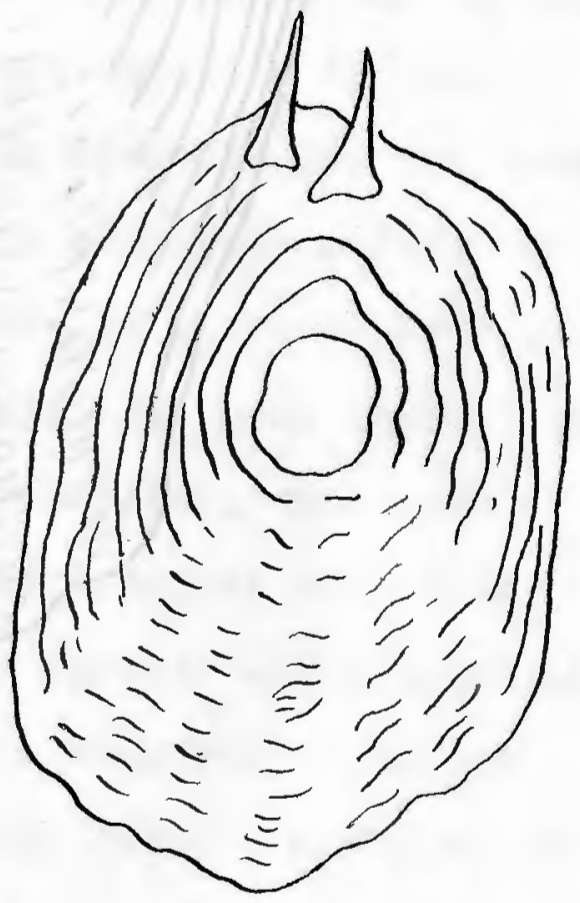

C. $32 \mathrm{~mm}$.

Figure 2

D. $41 \mathrm{~mm}$. 
$-19-$

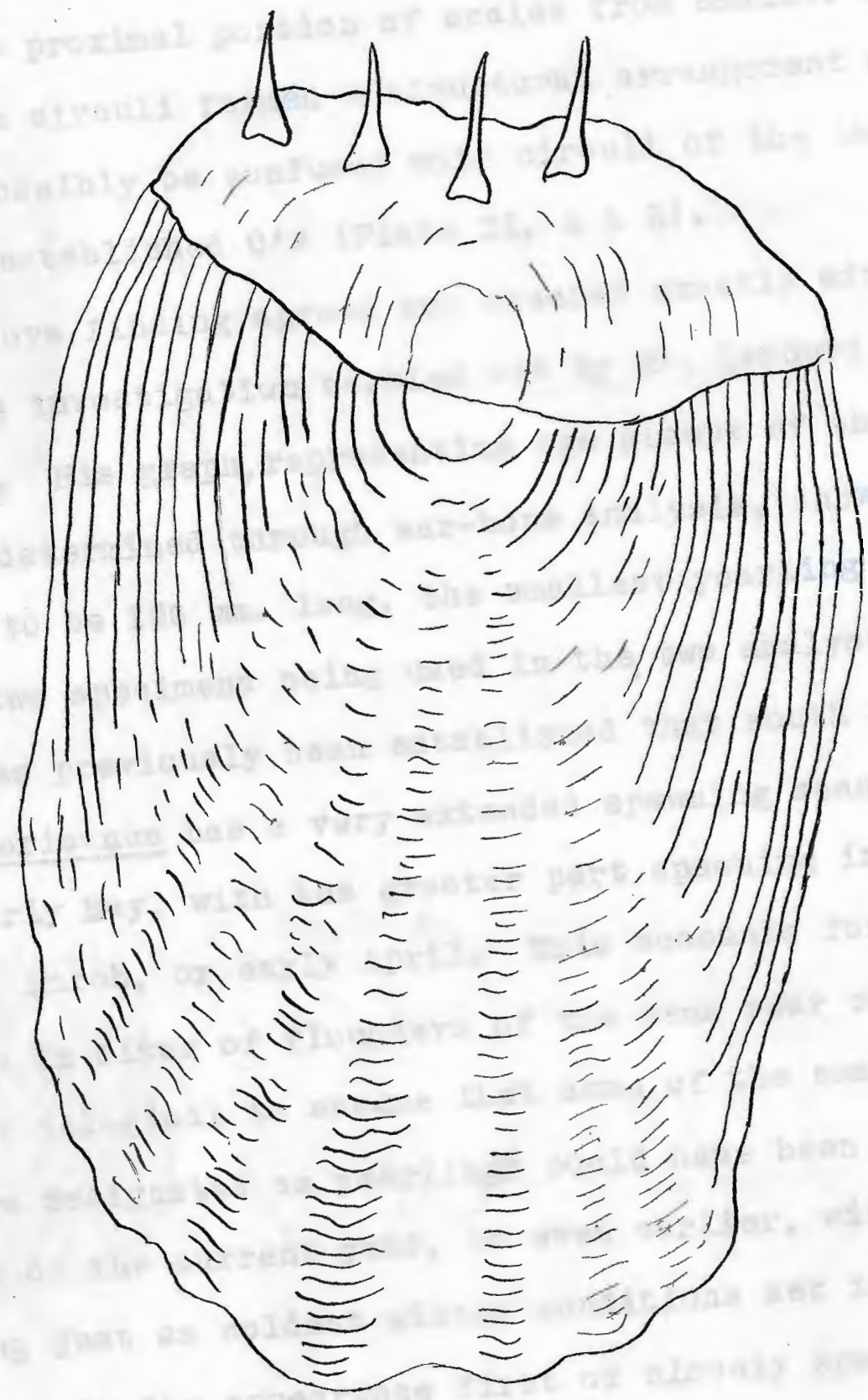

Figure 3

Scale from a $75 \mathrm{~mm}$ specimen 
crease in the number of eirculi, but in the spacing of the first 25-35 laid down, being very much closer together than those in the proximal portion of scales from smaller specimens. These circuli formed a structural arrangement which could not possibly be confused with cireuli of the largest previously established $O^{\prime}$ 's (Plate II, A \& B).

The above finding agreed and checked exactly with results of an investigation carried out by Mr. Landers on the same stock. His graph, representing age groups of the population as determined through ear-bone analysis, showed the largest 0 to be $136 \mathrm{~mm}$. long, the smallest yearling $138 \mathrm{~mm}$., the same two specimens being used in the two analyses.

It has previously been established that south of cape Cod $\underline{P}$. americanus has a very extended spawning season, December to early May, with the greater part spawning in late February, March, or early April. This accounts for the large variation in sizes of flounders of the same year class. Thus it is not illogical to assume that some of the smaller specimens here designated as yearlings could have been spawned in December of the current year, or even earlier, with scales appearing just as coldest winter conditions set in. This would explain the appearance first of closely spaced circuli, followed by more widely spaced circuli when rising spring temperatures occurred. Also in October (3lst), the ages of such fish actually would be slightly less than a year. How- 


\section{Plate II}
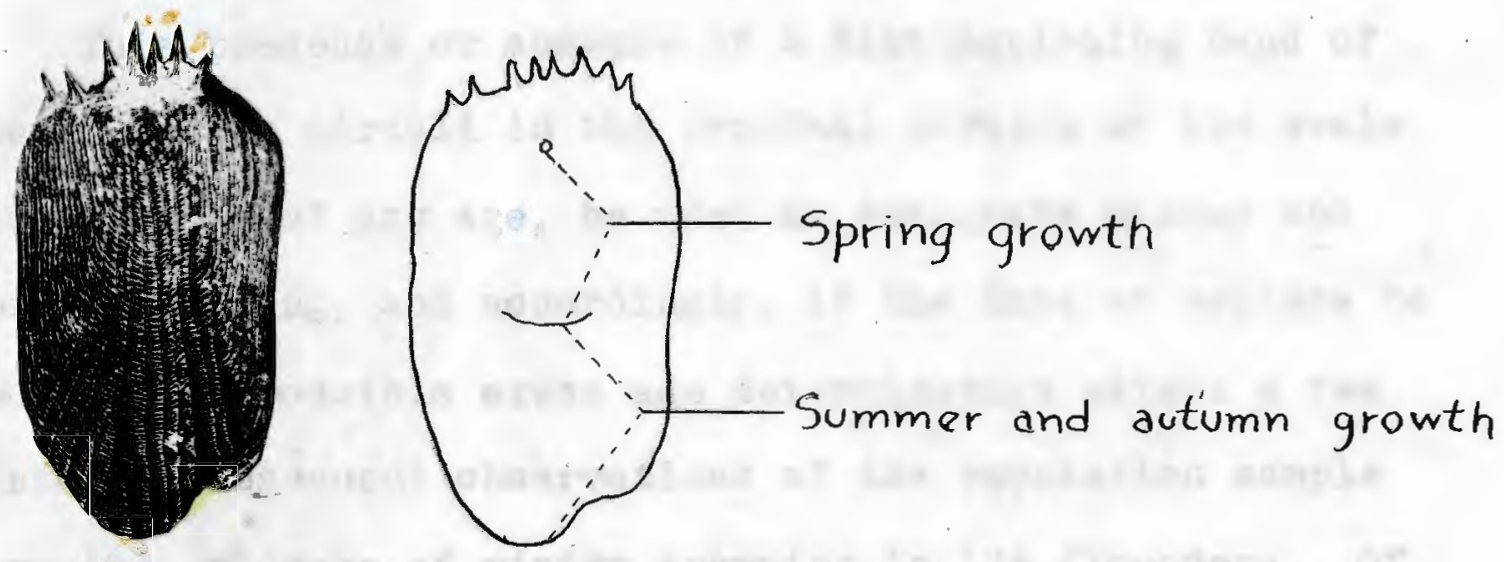

A. Largest 0
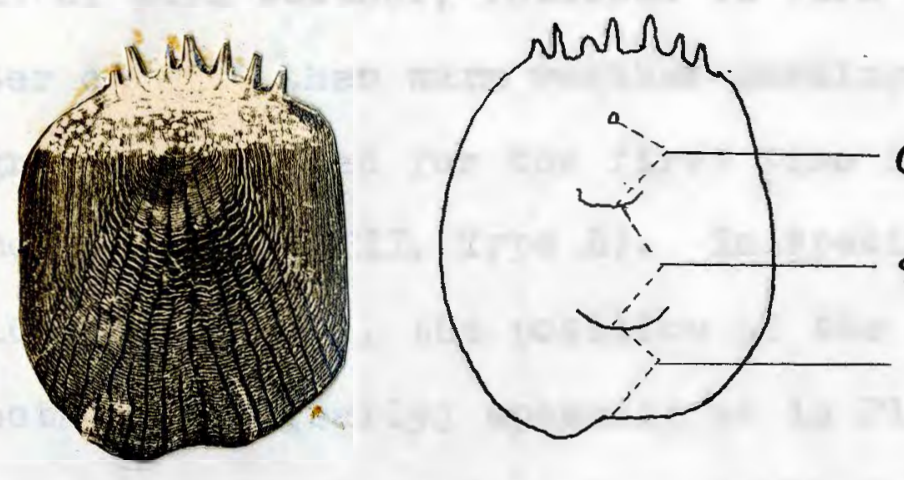

Circuli of winter
growth

spring growth

Summer and autumn

growth

B. Smallest yearling (winter-spawned) 
ever, since they show distinctly the banding characteristic of seasonal change, they have been referred to as winterspawned yearlings.

This presence or absence of a distinguishing band of winter growth circuli in the proximal portion of the scale can, in fish of any age, be used to designate winter and spring spawning, and accordingly, if the date of capture be known, make possible exact age determination within a few months. Subsequent observations of the population sample revealed evidence of winter spawning in 174 flounders. Of this group, 169 were between 138 and $195 \mathrm{~mm}$., three between 235 and $245 \mathrm{~mm}$., and two over $300 \mathrm{~mm}$. All specimens from 138 to $165 \mathrm{~mm}$. displayed this type of growth. Normal springspawned yearlings, exhibiting first the widely spaced eircuIi of warm weather, followed in turn by closely spaced winter circuli then warm weather markings of the second season's growth, appeared for the first time in flounders of 165 millimeters (Plate III, Type B). In specimens ranging between 165 and $195 \mathrm{~mm}$., the position of the winter bands indicated both winter (early) spawning as in PlateIII, Type A, and the normal spring spawning shown in Plate III. The winter bands in all specimens between $195 \mathrm{~mm}$. and $235 \mathrm{~mm}$. were of the spring-spawned type.

No difficulty was experienced in the separation of yearlings and two year olds by this method. The appearance of two winter bands was first observed in a $245 \mathrm{~mm}$. fish. Ear- 

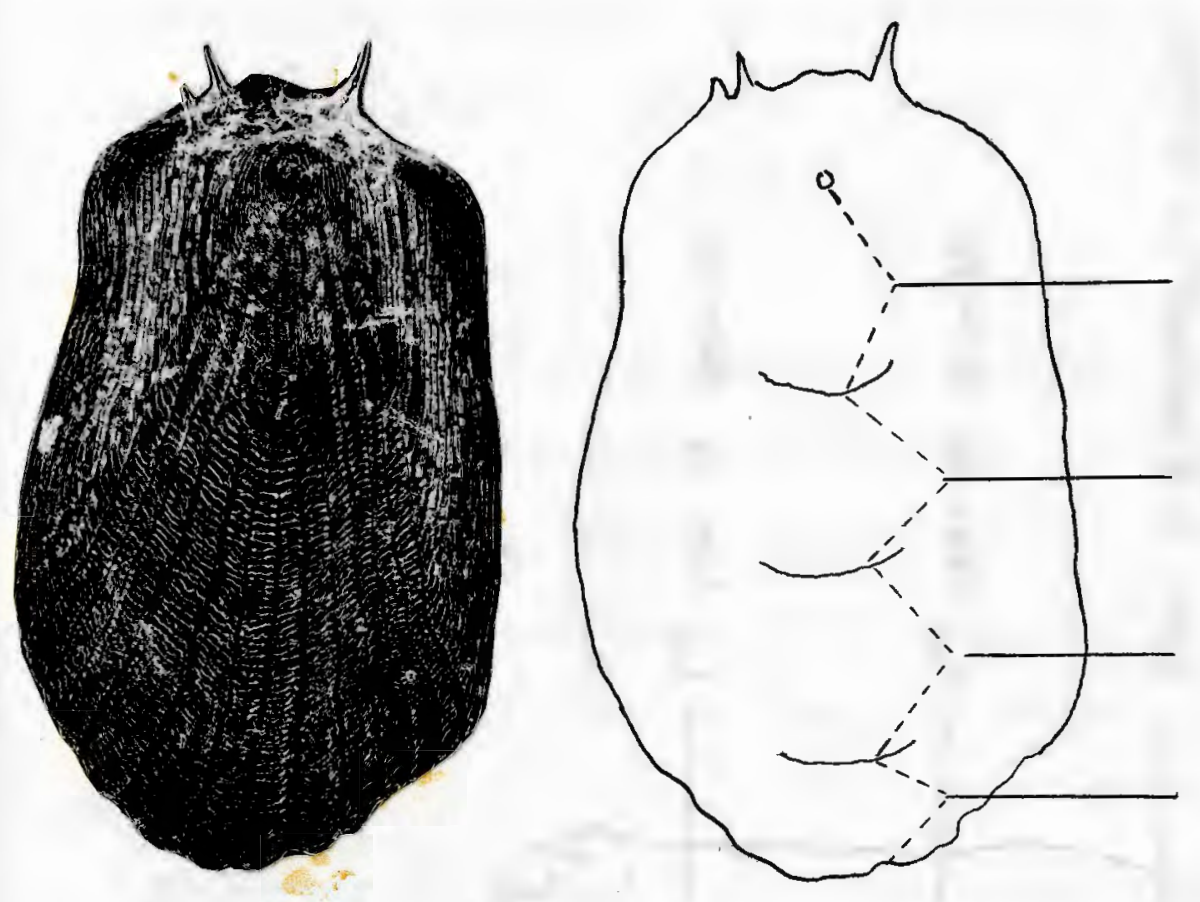

$1^{\text {st }}$ winter circuli

Spring growth

Summer growth

Late summer and autumn growth

A. Winter-spowned yearling
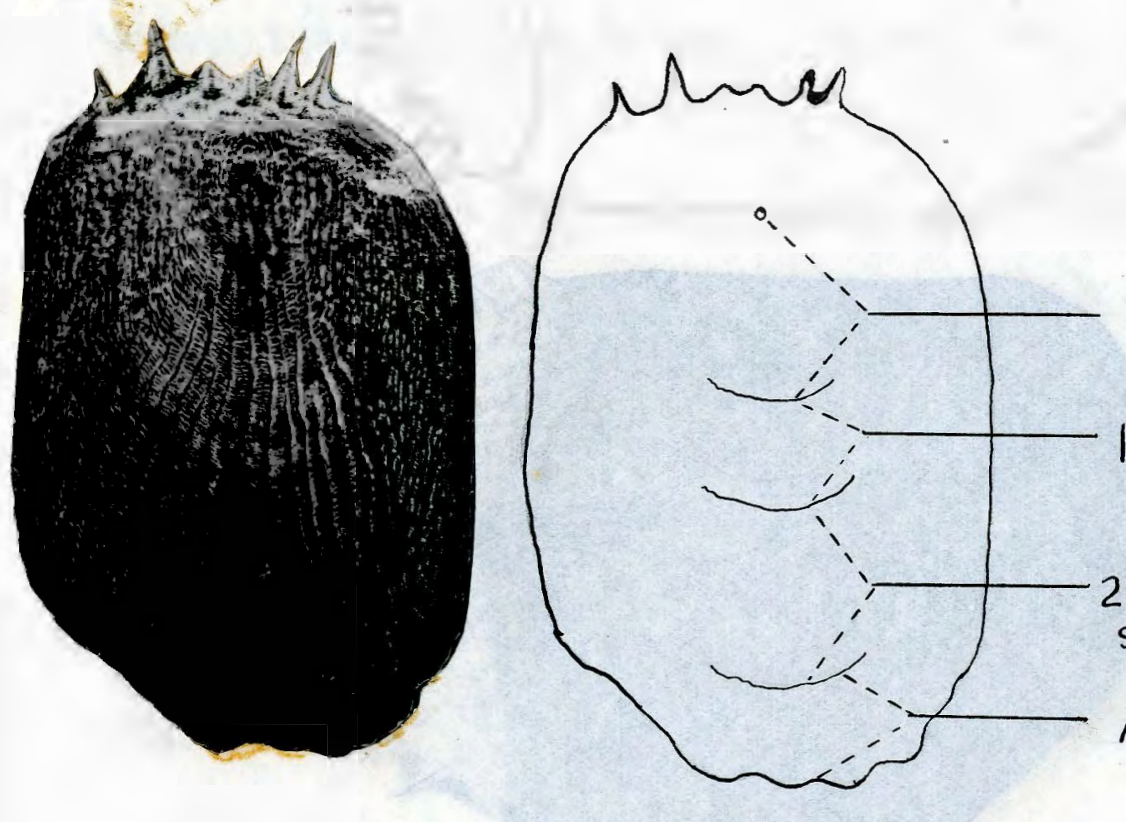

Ist spring and

summer growth

$1^{\text {st }}$ winter growth

$2^{\text {nd }}$ spring and

summer growth

Autumn growth

B. Spring-spowned yearling 


\section{Plate IV}
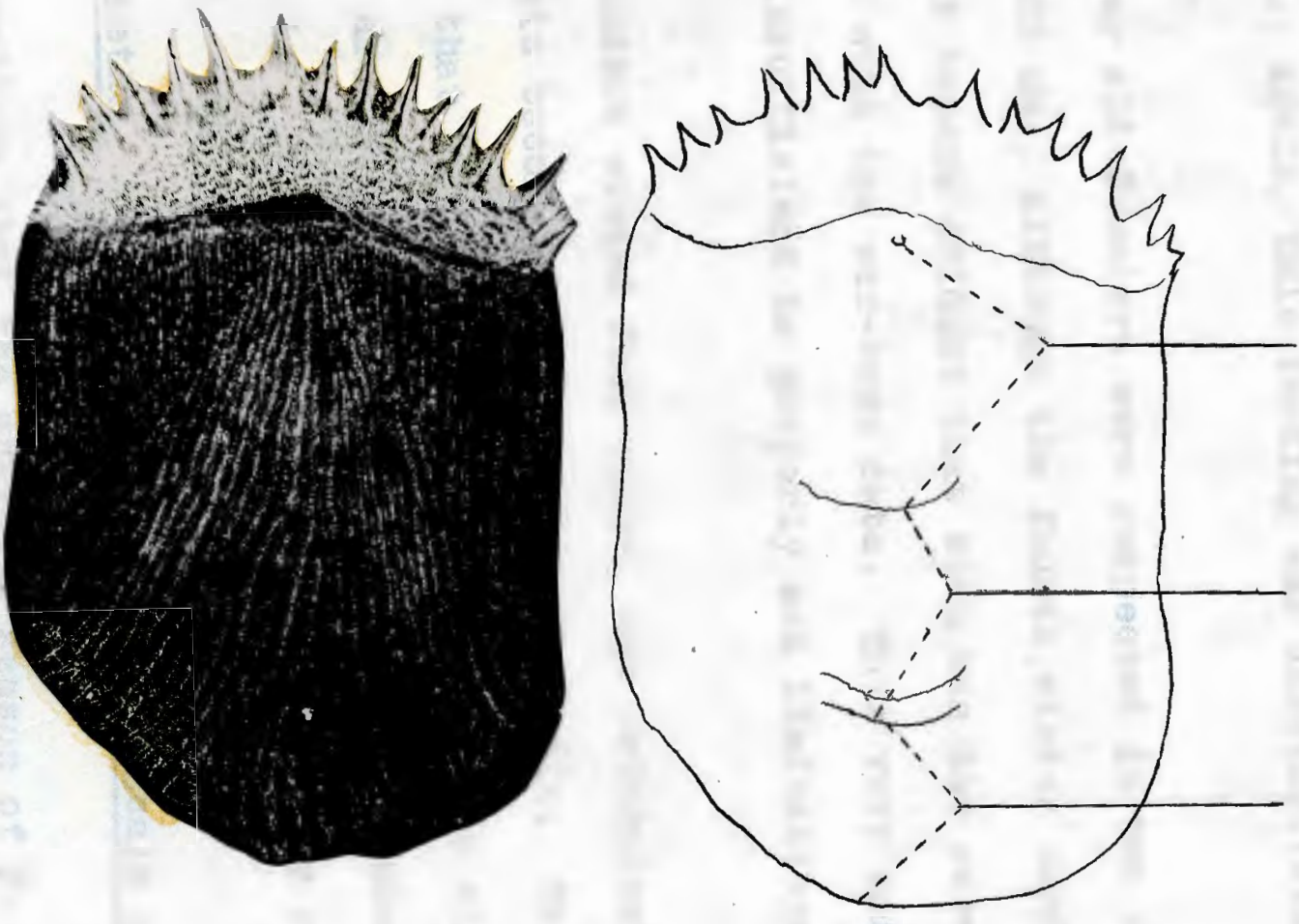

$1^{\text {st }}$ year of growth

Final 6-8 months of growth

Scale Showing Two Years and 6-8 Months of Growth 
bone readings to determine age showed the largest yearling to be $235 \mathrm{~mm}$. and the smallest two-year old as $245 \mathrm{~mm}$. Iong. A typical scale from a flounder of the latter class is reproduced in Plate IV.

Three-year olds were separated from two-year olds in the same manner, namely, the appearance of another or a third winter band, was first observed in a $300 \mathrm{~mm}$. specimen. Three such bands occurred in seven fish, the largest measuring $330 \mathrm{~mm}$. Again, this reading was substantiated by earbone results.

Four-year old flounders were suspected in two specimens of 345 and $355 \mathrm{~mm}$., although the fourth winter band was indistinct. It became evident that such was the case, however, when checked with the ear-bone data. This very small number of 4's was insufficient to properly set limitations for the class.

As flounders exceed four years, age determination by scale analysis becomes increasingly difficult. This is due to the fact that annual scale growth becomes so slow that the circuli are crowded together near the periphery, obliterating, in a large degree, summer and winter characteristics.

\section{Other Methods of Age Determination by Scale Analysis}

It is evident that the spawning season of $\underline{P}$. americanus differs in different localities according to climate, and 


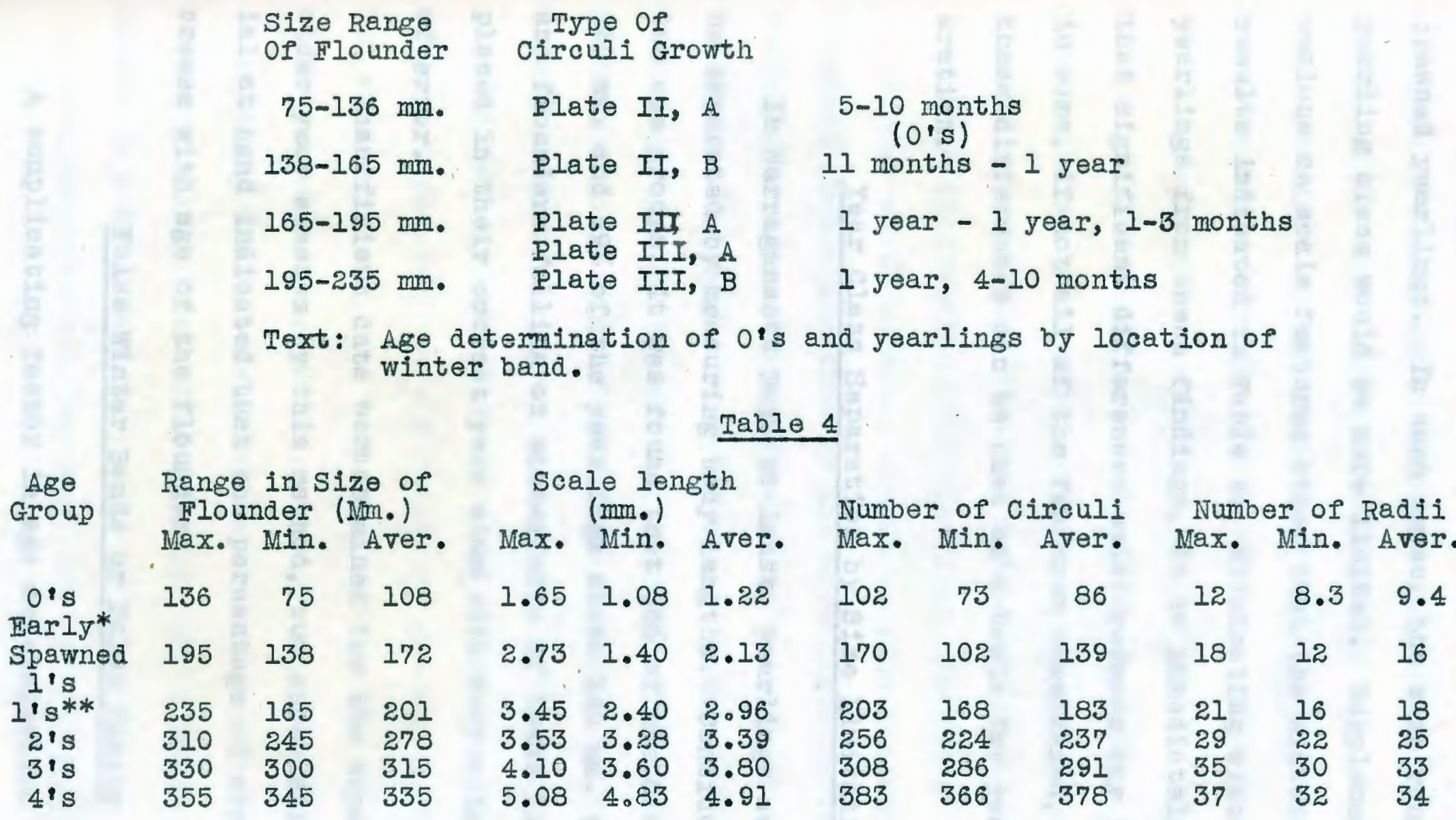

Text: Scale structures and size of $\underline{\underline{P}}$ americanus according to age groups. (0ct. 31,

*ish whose age is a year or slightly less.

* Fish whose age varies from one year 1 month to one year 10 months. 
northward from Narragansett Bay there may not be any winterspawned jearlings. In such areas, the size range of the yearling class would be more limited. Supplementary observations on scale features other than the winter bands yielded results indicated in Table 4. Eliminating winter-spawned yearlings from these findings, it is imediately apparent that significant differences exist between any two age groups in some, if not all of the features considered, and that these differences can be used as a basis for year class separation.

\section{Year Class Separation by Size Limitations}

In Narragansett Bay, at least, Jearlings and $0^{\prime} \mathrm{s}$ can be separated by measuring body lengths. Considering these two age groups, it was found that $93 \%$ of the 0 's were below $130 \mathrm{~mm}$. and $99 \%$ of the yearlings above $140 \mathrm{~mm}$. (0ct.). Thus any flounders falling on either side of these limits can be placed in their correct year class with very slight chance of error.

Insufficient data wereobtained for the separation of older year classes by this method, but observations on material at hand indicated that the percentage of error would increase with age of the flounder.

\section{False Winter Bands or False Checks}

A complicating factor in age determination of the winter 
flounder by scale reading is the frequent appearance of bands of circuli that show an abnormal rate of growth for the season In which they oceur. Rhode Island waters being in the southern limit of the range of $\underline{P}$. americanus, it may well be that excessive warming of the water, as well as excessive cooling, would have a decided effect upon its rate of growth. Dahl (1911), working on trout and salmon scales, concluded that injuries or adverse environmental conditions produced rings of growth that strongly resembled annuli.

Upon examination of scales from flounders of the autumn stock, one would normally expect to find a slowing down in marginal growth preceded by the more rapid growth of summer, shown in both cases by the relative spacing of the circuli. However, in a large number of scales examined, this did not hold true, for during the rapid growth of summer occurred a band of circuli similar to those laid down in the comparatively dormant period of mid-winter, followed by a moderately rapid growth approaching the margin. This marginal band could not possibly be the result of an entire spring, sumer, and autumn growth, and a logical conclusion is that for several weeks of excessively warm water, the flounder, if in a fairly shallow area such as Point Judith Pond, would become dormant, cease feeding, and show a corresponding decrease in growth rate.

Flounders of Trustom Pond, cut off for several weeks in 
July, 1940 from cool ocean water, became so lethargic that they would not move until touched, and many died. Scales from twenty of these specimens all showed an appreciable slowing down in marginal growth. This group, known to have been subjected to unnatural conditions, affords conclusive evidence that slowing down of growth rate and accompanying formation of false checks in scales are caused by excessively warm water.

It is, therefore, highly advisable if correct age is to be determined by scale reading with a minimum of trouble, that the time of capture, of the flounder be known. For example, one examining scales from winter flounders taken October 3lst, and not having information on the date of capture would very likely interpret the false checks that occur on a large percentage of the population sample as winter bands, and the increased marginal growth as the start of spring growth.

A typical false check is illustrated by the scale reproduction on Plate $V$ taken from a specimen $155 \mathrm{~mm}$. in length.

\section{Population Analysis}

Having devised a method by which the age of the winter flounder can be determined through scale analysis, it was applied to an analysis of a population sample of 509 fish obtained in October in Point Judith Pond. The age composi- 
$-30-$

Plate I
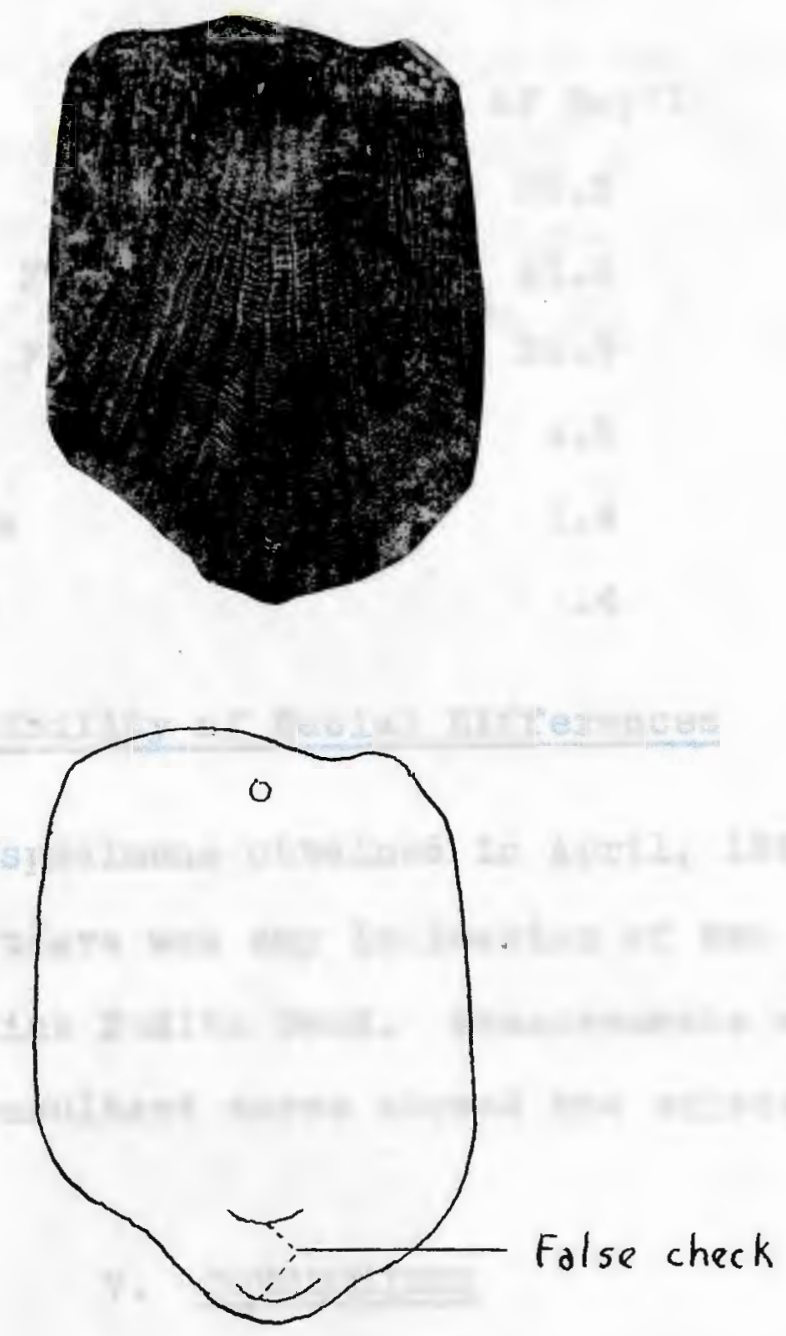

Scale Showing False Check (155 mm. specimen) 
tion of this population by the above method is represented in Fig. 6. Percentage composition of each age group is shown below.

\section{Table 5}

$\begin{array}{lc}\text { Age Group } & \% \text { of Pop'l. } \\ \text { O-year class } & 30.5 \\ \text { Winter-spawned yearlings } & 41.6 \\ \text { Spring-spawned yearlings } & 20.9 \\ \text { Two-year olds } & 4.5 \\ \text { Three-year olds } & 1.4 \\ \text { Four-year olds } & .4\end{array}$

\section{Possibility of Racial Differences}

The 208 small specimens obtained in April, 1941, were measured to see if there was any indication of two races of P. americanus in Point Judith Pond. Measurements were plotted (Fig. 5), and the resultant curve showed the existence of only one race.

\section{CONCLUSIONS}

1. Scales should be consistently taken from the same area on all fish to get a true scale reading. The area which has proven most indicative on $\underline{P}$. americanus is shown in Fig. 1 .

2. It is possible to determine the age of the winter flounder 
by scale analysis. In the young fish $\left(0^{\prime} \mathrm{s}\right)$, the time of capture should be known to avoid misleading interpretation of false checks as winter bands. However, after one winter band has been laid down, a comparison in size would eliminate a false check as a winter band.

3. There is conclusive evidence that in Point Judith Pond the winter flounder experiences a very extended spawing season, shown by the group of yearlings between 138 and $190 \mathrm{~mm}$. possessing winter circuli in the proximal portion of the scale. 






Fish

Length \& width (cm.)

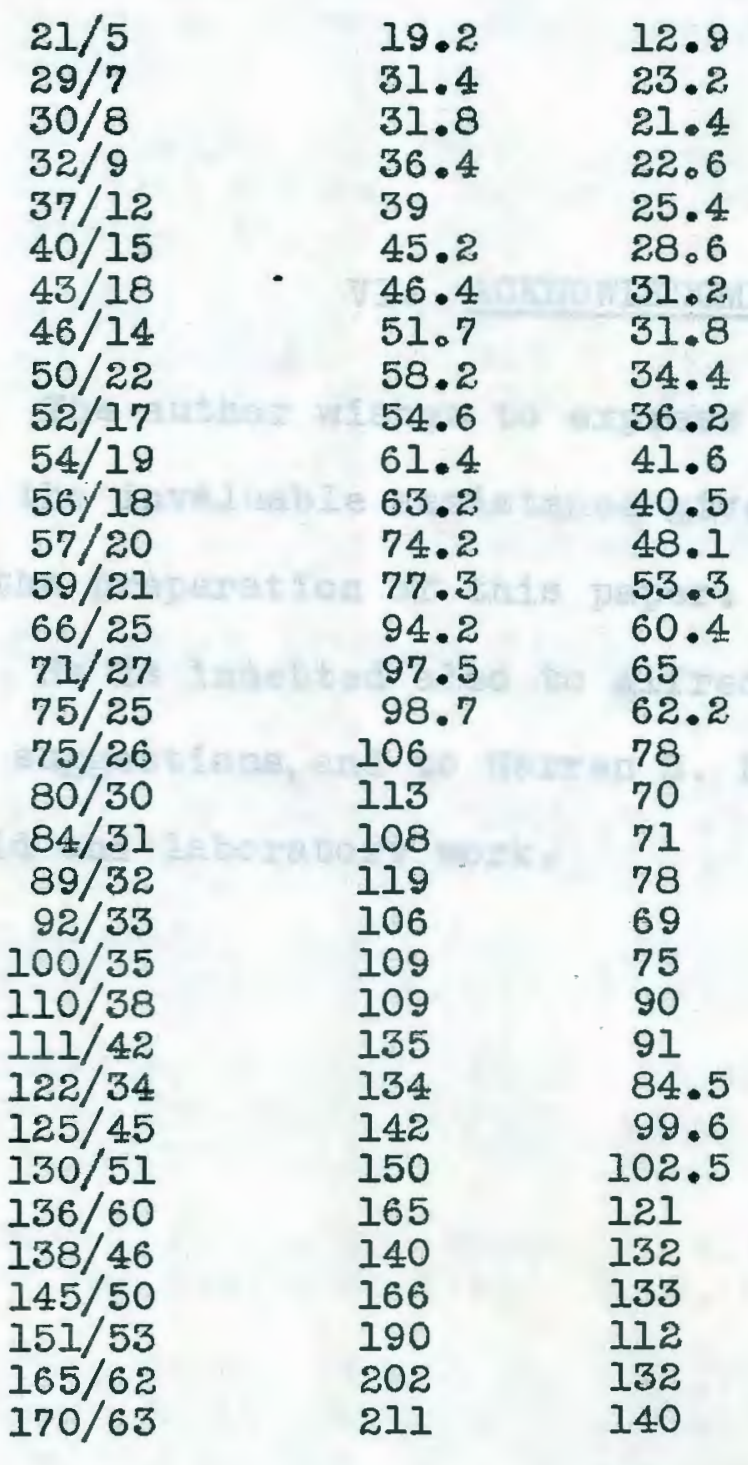

Length width Circuli Number of
Averages of Scales

$$
\text { (.01 m.) }
$$

Number of
Circuli
Radil

Table 2

$\begin{array}{cc}3.5 & 0 \\ 13 & 3 \\ 12.4 & 2.7 \\ 14.2 & 5 \\ 19 & 5.2 \\ 23.4 & 5 \\ 27 & 6.2 \\ 25.5 & 6.4 \\ 34.2 & 7 \\ 35.4 & 6 \\ 47 & 7.4 \\ 43.2 & 7.7 \\ 42.6 & 7.2 \\ 51.2 & 8.7 \\ 58 & 10.1 \\ 60 & 11 \\ 60.2 & 9 \\ 64 & 11 \\ 73 & 8.5 \\ 78 & 9.1 \\ 76 & 8.3 \\ 71 & 9.1 \\ 95 & 8.5 \\ 81 & 8.9 \\ 89 & 12 \\ 88 & 11.7 \\ 89 & 11 \\ 94 & 9.4 \\ 96 & 11 \\ 118 & 12 \\ 110 & 15 \\ 125 & 12 \\ 137 & 12 \\ 140 & 16\end{array}$

Text: Selected Series of Lengths. 


\section{ACKNOWLEDGMENTS}

The author wishes to express his sincere appreciation for the invaluable assistance given by Dr. Charles J. Fish in the preparation of this paper.

He is indebted also to Alfred Perlmutter for very helpful suggestions, and to Warren $S$. Landers for assistance in Pield and laboratory work. 


\section{BIBLIOGRAPHY}

Literature Citea

1. Creaser, Chas. W., 1926 - Structure and Growth of the Scales of Fishes in Relation to their Life History, with Special Reference to the Sunfish, Eupomotis gibbosus. Univ. of Mich. Publ. Misc. Publ. No. 17. Museum of 200logy.

2. Dahl, Knut, 1911 - Age and Growth of Salmon and Trout in Norway as Shown by their Scales. Salmon and Trout Assoc'n. Iondon.

3. Rae, Bennet B., 1939 - Age and Growth of Lemon soles in Scottish Waters. Fisheries Board for Scotland. Scientific Invest. No. 1: 1-39.

4. Taylor, H. F., 1914 - Structure and Growth of the Scales of the Squeteague and the Pigfish as Indicative of Life History. U. S. B. F. Bull. Vol. XXXIV: 285-330.

\section{Literature Examined}

1. Bigelow, H., 1934 - Fishes of the Gulf of Maine. U. S. B. F. Publ. Part 1. Vol. XI

2. Brown, Wallace, 1901-1903 - Some Observations on the Young Scales of the cod, Haddock, and Witing before shedding. Proc. Roy. Soc. Edinburgh. Vol. XXIV: 437-438.

3. Cockerell, T. D., 1912 - Observations on Fish Scales. U. S. B. F. Bull. Vol. 32: 117-174.

4. Esdaile, Philippa, 1912 - Intensive Study of the Scales of Three Specimens of Salmo salar. Manchester Literary and Philosophical soc. Tol. 56. part I memoir III.

5. Green, E. H., and Tower, R. W., 1901 - Organic Constituents of the Scales of Fish. U. S. B. F. Bull. Vol XXI:97-102.

6. Hile, Ralph, 1936 - Age and Growth of the Cisco in the Lakes of the Northeastern Highlands, Wisconsin. U. S. B. F. Bul1. No. 19. Vol. XIVIII:218-226.

7. Hannah, T. H., 1873 - On the Scales of Fish. Brighton and Sussex Nat. Hist. Soc. 20th Annual Report: 55-57 
8. Huntsman, A. G., 1919 - Growth of Scales in Fishes. Trans. Roy. Canadian Inst. Vol. 12: 61-101.

9. Hutton, J. A., 1909 - Salmon Scales as Indicative of the Life History of the Fish. $27 \mathrm{pp}$. XIV pl. London.

10. Johns Von, H. W., 1905 - Scales of the Tay Salmon as Indicative of Age, Growth, and Spawning Habit. Fish Board for scotland. Annual Report 23. pt. 11: 63-79.

11. Lee, Rosa M., 1920 - A Review of the Methods of Age and Growth Determination in Fishes by Means of Scales. Fish. of Fngland and Wales. Minister of Agri. and Fish. Fish. Invest. Series II Vol. 4. No. 2: 1-32.

12. Marshall, N., 1939 - Annulus Formation in Scales of the Common Shiner, Notropis cornutus chrysocephalus Copeia. No. 3. Sept. 9: 148-154.

13. Masterman, A. T., 1913 - Report on Investigation upon the :Salmon with Special Reference to Age Determination by study of Scales. Board of Agri. and Fish. Fish. Invest. Series I. Salmon and Fresh Water Fisheries Vol. I: 1-80.

14. Milne, J. A., 1913 - Pacific Salmon: An Attempt to Evolve Something of their Life History from Examination of their Scales. Proc. Zoo. Soc. London: 572-610.

15. McMurrich, J. P., 1912 - Life Gycles of the Pacifio Coast Salmon, Oncorhyncus, as Revealed by their scale and otolith Markings. Roy. Soc. of Canada. Sect. IV: 9-29.

16. Thompson, Harold, 1923 - Problems in Haddock, with Special Reference to the Validity and Utilization of the Scale Theory. Prelim. Report. Fish. Board for Scotland. Sci. Invest. Edinburgh.

17. Thomson, J. S., 1904 - Periodic Growth of Scales in Gadidae as an Index of Age. Journ. Marine Biol. Assoc'n. Vol. 7: 1-109.

18. 1929 - Iife History of the Lake Herring of Lake Huron as Revealed by its Scales, and a Critique of the Scale Method. U. S. B. F. Bull. Vol. XIIX. Washington: 265-428.

19. Winge, 0., 1915 - On the Value of the Rings in the scales of the Cod as a Means of Age Determination, Illustrated by Marking Experiments. Medd. Komm. Havunders, ser. Fiskeri, Bd. 4 res. 8: 1-2l. 